Conference Theme:

\title{
CONFERENCE ON THE TEACHING OF FOREIGN LANGUAGES
}

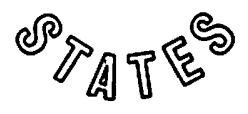

\section{"SPIRIT OF '76: FREEDOM TO COMMUNICATE"}

Date: April 22-24, 1976 (As always, the weekend after Easter.)

CirY: Detroit, Michigan. Detroit Heritage Hotel

KEYNOTE ADDRESSES: - Intercultural Communication

- Communicative Competence: Theories and Classroom Applications

- Interpersonal Communication in the Classroom

OTHER Highlights:

- Theme Banquet and Luncheon speakers.

- 22 special interest sessions.

- 6 workshop sessions.

- 5 specific language sessions.

- Thursday Eve Special: "Wine and Cheese Fete." An evening for good food, company and dancing.

Companies or organizations wishing to exhibit or advertise; anyone seeking Advisory Council membership, and persons interested in receiving Conference Program Booklet containing registration and hotel reservation forms should write to: William Clapper, Roanoke County Schools, 526 College Avenue, Salem, Virginia 24153 (703) 389-0861 


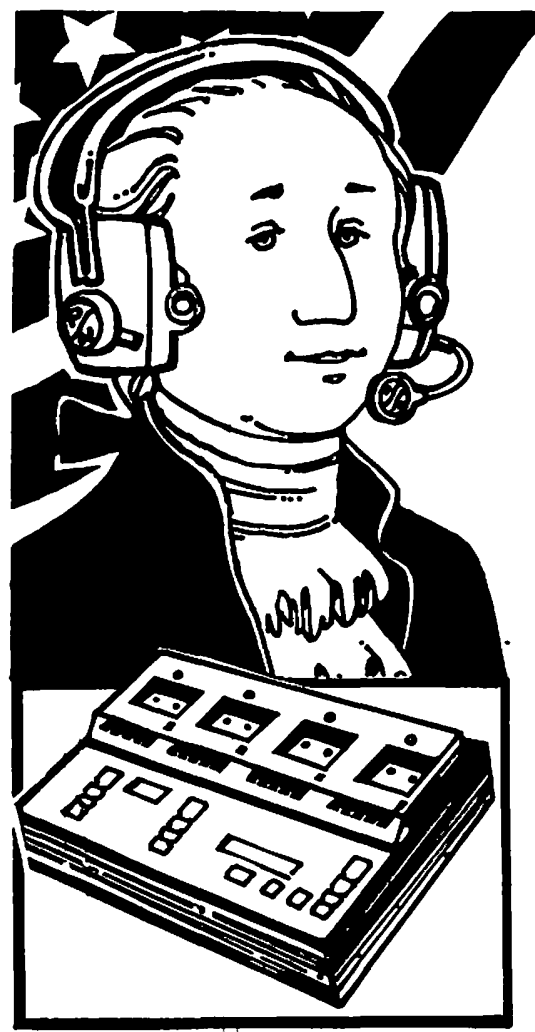

\section{"ICannot Tell ALie..."}

$\mathrm{P} / \mathrm{H}$ really does have wireless, two-way monitor-intercom

\section{MONI-COM II ${ }^{\mathrm{TM}}$}

The perfect system for teaching foreign languages .... with 6-channel wireless receiver/headsets.

Exclusive, patented MONI-COM II feature permits teacher to monitor each student, without his knowledge, or talk to any one student and not disturb the other students. Even record any student $\therefore$. both his program and his responses ... on separate tracks on a recorder built into the console.

Compact: $26^{\prime \prime} \times 18^{\prime \prime} \times 8^{\prime \prime}$. . Console easy for teachers and teacher aids to use.

Move the console anywhere in the school ... broadcast as many as six programs to students within a room.

Another first from $P / H$... manufacturers of 2 to 12-channel one-way wireless systems for the classroom and instructional media centers.

For a freo, dynamic, no-obligation demonstration in your school, contact . . .

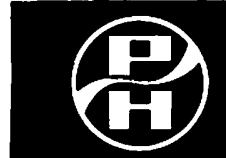

P/H ELECTRONICS

A Division of Duncan Electric Company

117 E. Helena Street/Dayton, Ohio 45404/513-461-5898

Please mention the NALLD Journal when writing advertisers 


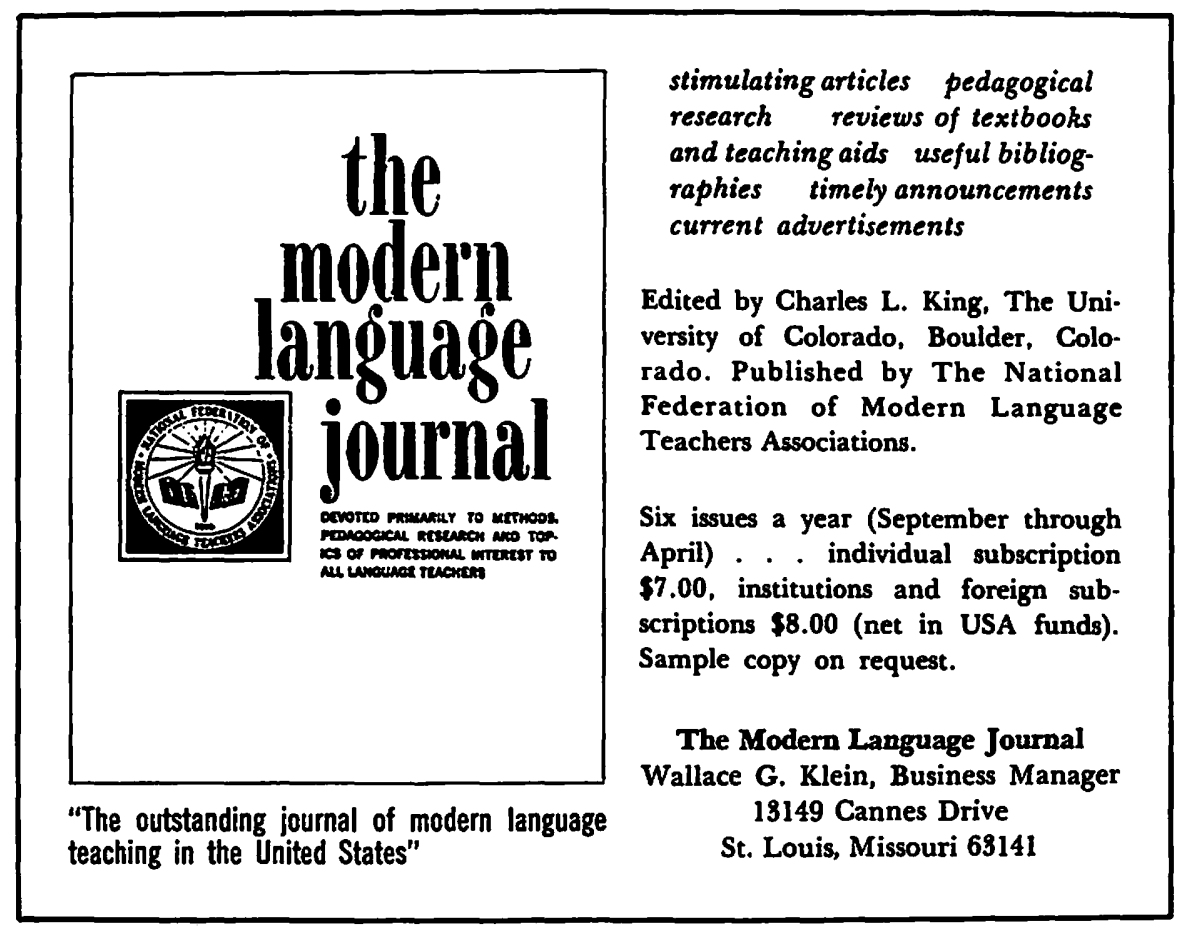

\section{PERSPECTIVES}

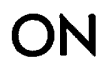

\section{CONTEMPORARY LITERATURE}

A New Bi-Annual Publication of the

CONFERENCE ON TWENTIETH CENTURY LITERATURE

VOLUME I-1975 THE ALIENATED MAN

VOLUME ॥-1976 LITERATURE AND REVOLUTION

SUBSCRIPTION RATE: $\$ 5.00$ PER VOLUME

CHECKS SHOULD BE MADE PAYABLE TO

PERSPECTIVES ON CONTEMPORARY LITERATURE

MAILING ADDRESS: EDITOR

PERSPECTIVES ON CONTEMPORARY LITERATURE

UNIVERSITY OF LOUISVILLE

LOUISVILLE, KY. 40208 


\section{Would YOU Like to Help the NALLD Journal? HERE'S HOW}

Clip and send the following memo to your school librarion

TO:

FROM:

Could you please subscribe to the NALLD Journal?

The library rate is $\$ 9$. With a three year subscription you will re ?eive a complete set of back issues.These back issues may be purchased separately at $\$ 5.00$ per volume.

Make checks payable or send request to:

James Ek

Treasurer NALLD

Language Dept.

Western Michigan University

Kalamazoo, Michigan 49001

\section{NATIONAL ASSOCIATION OF LANGUAGE LABORATORY DIRECTORS NALLD JOURNAL}

\begin{tabular}{|c|c|}
\hline Name. & MEMBERSHIP \\
\hline te & $\square$ New Member \\
\hline Institution & $\begin{array}{l}\text { U.S.A. (SO states) } \\
\text { Canada } \\
\text { Foreign Air Mail } \\
\text { Student (non-voting) }\end{array}$ \\
\hline $\begin{array}{l}\text { Address to which NALLD JOURNAL is to } \\
\text { be sent: }\end{array}$ & $\begin{array}{l}\text { Return this form to: } \\
\text { James Ek }\end{array}$ \\
\hline Address ..... & $\begin{array}{l}\text { Treasurer NALLD } \\
\text { Language Dept. }\end{array}$ \\
\hline City $\ldots \ldots \ldots$ & $\begin{array}{l}\text { Western Michigan University } \\
\text { Kalamazoo, Michigan } 49001\end{array}$ \\
\hline $\begin{array}{l}\text { y school is paying the } \\
\text { embership. Send the in }\end{array}$ & $\begin{array}{l}\text { Commercial organizations are invited } w \\
\text { contact NALLD regarding associate member. } \\
\text { ship. }\end{array}$ \\
\hline
\end{tabular}




\section{THIS SPACE \\ COULD HAVE BEEN YOURS!}

FOR ADVERTISING RATES

WRITE:

Mr. Gary Mann

Listening Center

Dieter Cunz Hall

Ohio State University

Columbus, Ohio 43210

(tel. 614-422-2850) 


\section{Sony's grand opening of the first mobile language lab.}

With Sony's MOBILAB ${ }^{\mathrm{TM}}$, languages can be taught in any room, under a tree, even sur la plage. And MOBILAB can go from school to school for maximum utilization with minimum equipment cost.

It's about the same reasonable price as a wireless installation, but without that poor wireless sound that has teachers everywhere crying "oncle!"

On the other hand, fixed labs do have good sound, true. But the cost? Gott im Himmel!

MOBILAB gives you the quality sound of a fixed lab but at a much lower cost.

But no other system, fixed or wireless, offers as much operating ease and teaching flexibility: all three teaching levels plus independent study (the students can take the player/recorders with them). Each of the compact MOBILAB cabinets includes console, teacher player/ recorder, 10 student player/ recorders, and headsets for all.
Two or more MOBILAB units can be quickly, easily coupled to instruct any number of students.

"iUn sistema maravilloso de lengua!" can now be very clearly enunciated, anywhere, with the portable MOBILAB. Write to the Sony Information Center NAL-1I5 for further information.

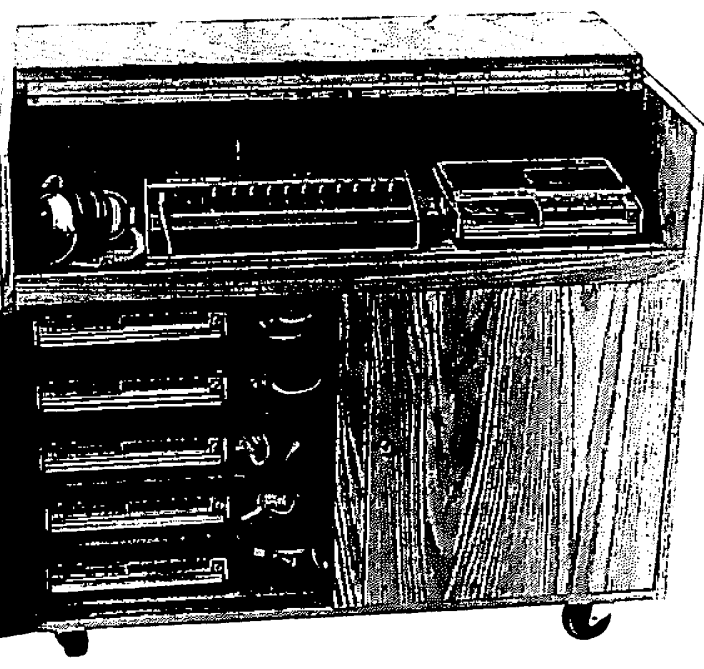

\section{Sony: Quality Learning Systems.}

